Nippon Suisan Gakkaishi $\quad$ 86(5), 360-363 (2020)

\title{
令和元年度水産学技術賞
}

\author{
高温耐性ニジマスの作出と高温耐性の生物学的評価 \\ 稻野俊直, ${ }^{*} *$ 田牧幸一, 2 山田和也 ${ }^{3}$ \\ 1近畿大学水産研究所, 2 公益社団法人宮崎県漁村活性化推進機構, 3宮崎県農政水産部水産政策課
}

Production of thermally tolerant rainbow trout and biological evaluation of thermal tolerance

TOSHINAO INENO, ${ }^{*}$ KOICHI TAMAKI² AND KAZUYA YAMADA ${ }^{3}$

${ }^{1}$ Aquaculture Research Institute, Shingu Station, Kindai University, Shingu, Wakayama 647-1101, ${ }^{2}$ Miyazaki Fishing Communities Revitalization organization, Miyazaki, Miyazaki 880-0858, ${ }^{3}$ Miyazaki Prefecture, Agriculture and Fisheries Department, Fisheries Administration Division, Miyazaki, Miyazaki 880-8501, Japan

はじめに

宮崎県には 1911 年（明治 44 年）に初めてニジマス Oncorhynchus mykiss が移植され御池に放流された。そ の後, 1960 年代に長野県や岐阜県等から養殖用として 宮崎県水産試験場にもたらされたニジマスによって, 種 苗生産技術開発が行われた。同じ頃, 宮崎県水産試験場 は, 水温が高い平野部でも飼育できるニジマス品種の改 良に取り組むようになった。

1966 年に始めたニジマスの選抜淘汰は, 夏季に産卵 期前の 1 歳魚を高水温（最高 $27^{\circ} \mathrm{C}$ 程度）にした水槽で 飼育して, 生残個体を親魚にして次世代の生産を繰り返 す方法であった。また，1971～1977，1985～1992 年打 よび 1998 年の夏季に 1 歳魚を $30 \sim 35^{\circ} \mathrm{C} に 1 \sim 5$ 分間浸 漬して同様の選抜淘汰を行った。そして飼育試験や民間

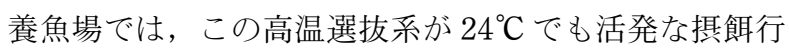
動を示し, 生残率も高いと評価されることもあったが, その生理機構は科学的に検証されていなかった。また, 外部の研究機関からは必ずしも一定の評価が得られてい なかった。そこで高温選抜系の高温耐性について, 生物 学的評価を行い更なる選抜手法の改良に取り組んだ。

\section{1. 受精卵之稚魚の高温耐性}

授精・京化水温, 系統, 発生段階の違いによる受精卵 の半数致死温度 $\left(\mathrm{LT}_{50}\right)$ を比較した。由来が明確な標 準系ニジマス（ドナルドソン系）々高温選抜系のそれぞ れの卵を 10 および $14^{\circ} \mathrm{C}$ で授精した肧を用いて, 授精 時の水温で卵割初期, 胞肧期, 神経肧期に達した肧につ いて, $10^{\circ} \mathrm{C}$ 授精胚は $13 \sim 19^{\circ} \mathrm{C}$ の 7 通り， $14^{\circ} \mathrm{C}$ 授精胚 は $17 \sim 21^{\circ} \mathrm{C}$ の 5 通りの水温に扔いて $7.5,15,30,60$,
180，360，720，1,440 分間暴露して授精時と同じ水温 でふ化率を求めた。 その結果を基に暴露時間毎に $\mathrm{LT}_{50}$ を算出したところ, 10 および $14^{\circ} \mathrm{C}$ 授精胚はいずれも暴露時間の延長に伴い 低下した。 $10^{\circ} \mathrm{C}$ 授精肧の $\mathrm{LT}_{50}$ は, 胞肧期の 1,440 分間 暴露に打いて高温選抜系 $\left(15.1^{\circ} \mathrm{C}\right)$ は, 標準系 $\left(13.5^{\circ} \mathrm{C}\right)$ より有意に高かったが，卵割初期では $17.4^{\circ} \mathrm{C}$ と $17.3^{\circ} \mathrm{C}$, 神経肧期では $15.7^{\circ} \mathrm{C}$ と $14.0^{\circ} \mathrm{C}$ と, $\mathrm{LT}_{50}$ に系統間の差 はなかった。一方, $14^{\circ} \mathrm{C}$ 授精胀の $\mathrm{LT}_{50}$ は, いずれの発 生段階に颃いても高温選抜系は標準系より高く, 両系統 の $\mathrm{LT}_{50}$ の差は, 卵割初期, 胞胚期および神経胚期でそ

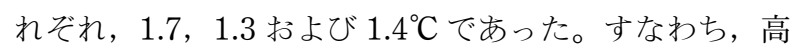
温選抜系の受精卵は, $10^{\circ} \mathrm{C}$ では胞肧期, $14^{\circ} \mathrm{C}$ では卵割 初期, 胞胚期および神経胚期において標準系より $\mathrm{LT}_{50}$ が高く, 受精卵において高温耐性の形質を獲得している ことが示唆された。

稚魚についても高温選抜系と標準系を対象に，24～ $29^{\circ} \mathrm{C}$ に扔いて $1^{\circ} \mathrm{C}$ 間隔で試験区を設定し，稚魚を 0.5 96 時間暴露して各試験区の死亡数を記録し $\mathrm{LT}_{50}$ を求め た。3〜12 時間暴露では, 系統間で差は認められなかっ たが， 72 時間の $\mathrm{LT}_{50}$ は高温選抜系 $\left(25.8^{\circ} \mathrm{C}\right)$ が標準系 $\left(24.3^{\circ} \mathrm{C}\right)$ より高かった。

次に, 予め $15^{\circ} \mathrm{C}$ まは $20^{\circ} \mathrm{C}$ に馴致した高温選抜系 と標準系（ドナルドソン系抢よび長野産）の稚魚（3.0 $\sim 24.2 \mathrm{~g})$ を対象に, $5^{\circ} \mathrm{C} /$ 時間で水温を上昇させて臨界 最高温度 (CTM) と死亡温度（DT）を比較した。

その結果, $15^{\circ} \mathrm{C}$ 馴致の高温選抜系抢よび長野産とも にCTM は29.6, $29.7^{\circ} \mathrm{C}, \mathrm{DT}$ は $30.0,30.1^{\circ} \mathrm{C}$ と差が なく, $20^{\circ} \mathrm{C}$ 馴致でも高温選抜系と長野産の CTM は双

* Tel : 81-735-29-0001. Fax : 81-735-29-0147. Email : ineno@kindai.ac.jp 
方 $30.4^{\circ} \mathrm{C}$ で差がなかったが，ドナルドソン系 $\left(29.9^{\circ} \mathrm{C}\right)$ より高かった。DT は, $20^{\circ} \mathrm{C}$ 馴致の高温選抜系, 長野 産抢よびドナルドソン系に打いて，それぞれ $30.9^{\circ} \mathrm{C}$, $30.6^{\circ} \mathrm{C}$ 抢よび $30.2^{\circ} \mathrm{C}$ 上, 高温選抜系が標準系の 2 系統 より高かった。このように CTM と DTは, $15^{\circ} \mathrm{C}$ 馴致 では差が認められなかったが， $20^{\circ} \mathrm{C}$ 馴致では高温選抜 系が高くなる傾向を示し, 馴致温度が高い程, 高温耐性 が強くなることが示唆された。

以上のように, 高温選抜系は受精卵や稚魚において, ある程度の高温耐性を獲得していると考えられた。

\section{2. 高温飼育下における摂餌}

前述の生物学的指標では, その差は僅かしかなく高温 選抜系の有用性を説明することは難しかった。養殖規模 で高温選抜系を飼育すると, 高水温期にも摂饂活性が衰 えないという印象を受けることから, 高温選抜系と標準 系（ドナルドソン系）の掑䬣率を高温飼育下において自 発摂䭒装置を用いて比較した。

平均体重 7.5 および $8.7 \mathrm{~g}$ の両系統を 50 尾ずつ供し て, 17.5 から $25.7^{\circ} \mathrm{C}$ まで, 平均 $0.3^{\circ} \mathrm{C} /$ 日の昇温速度で 21 日間かけて緩やかに水温を上昇させたところ, 日間 拱餌率は標準系 (4.1\%) に対して高温選抜系 (7.1\%) が高かった。

次に平均体重 22.4 および $22.6 \mathrm{~g}$ の両系統を 37 尾ず つ供し, 水温を $0.5^{\circ} \mathrm{C} /$ 日で 13 日間かけて $24.1^{\circ} \mathrm{C}$ に上昇 させたところ, 18 日目までは両系統間の日間拱䬣率に 差は認められなかったが, それ以降の日間摂䭒率は, 高 温選抜系 $(0.8 \%)$ が標準系 $(0.2 \%)$ より高い状態を維 持した。

さらに平均体重 34.8 抢よび $34.1 \mathrm{~g}$ の両系統を 27 尾 ずつ供し, 水温を $16.7^{\circ} \mathrm{C}$ から $21.7^{\circ} \mathrm{C}$ へ 1 日で急上昇 させ, 以降 28 日間かけて $0.1^{\circ} \mathrm{C} /$ 日で $24.4^{\circ} \mathrm{C}$ に緩やかに 水温を上昇させたところ, 昇温直後から標準系の日間掑 䬣率は低下し $0.1 \%$ を示したのに対して, 高温選抜系 (1.0\%) は高い状態を維持した。

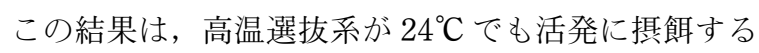
特性を裏付けるものであった。

\section{3. 育種を目的とした系統間の交配と高温耐性}

稚魚（3.0〜 24.2 g ）のCTM を比較した実験におい て,ドナルドソン系（宮崎県水産試験場で継代飼育）は 高温選抜系より有意に低いCTM の值を示した。1）そこ で, 高温耐性の低い系統を高温選抜系と交配してF1を 作出するため, 2 系統のドナルドソン (青森系と日光系) の親世代 F0 の CTM を測定して, 同時に測定した高温 選抜系と比較した。

$15^{\circ} \mathrm{C}$ 馴致した 3 系統の $\mathrm{F} 0$ の $\mathrm{CTM}$ は, $29.1 \sim 29.2^{\circ} \mathrm{C}$ であり, 差が認められなかったが， $20^{\circ} \mathrm{C}$ 馴致では, 日
光系 $\left(29.7^{\circ} \mathrm{C}\right)$ は, 青森系 $\left(29.9^{\circ} \mathrm{C}\right)$ 抢よび高温選拔系 $\left(30.0^{\circ} \mathrm{C}\right)$ より $\mathrm{CTM}$ が低く, 以前の研究を支持する結 果であった。各系統の CTM は, $20^{\circ} \mathrm{C}$ 馴致が $15^{\circ} \mathrm{C}$ 馴致 より高い值を示し，その差は高温選抜系 $\left(0.9^{\circ} \mathrm{C}\right)$, 青森 系 $\left(0.7^{\circ} \mathrm{C}\right)$, 日光系 $\left(0.4^{\circ} \mathrm{C}\right)$ の順に大きかった。馴致 温度 $\left(10,15,20^{\circ} \mathrm{C}\right)$ と CTM には高い正の相関があ り，その傾きは， $0.18^{\circ} \mathrm{C}$ であったとの報告がある。 ${ }^{2)}$ 高 温選抜系でも同様の CTM の上昇が認められ, $20^{\circ} \mathrm{C}$ 馴 致の高温選抜系の $\mathrm{CTM}$ は, 同報告の $15^{\circ} \mathrm{C}$ 馴致 (29.1 温選抜系の $\left.{ }^{\circ} \mathrm{C}\right), 20^{\circ} \mathrm{C}$ 馴致 $\left(29.8\right.$ 温選抜系の $\left.{ }^{\circ} \mathrm{C}\right)$ より 高い值を示していた。高温耐性は, 遺伝的差異 3 ) や馴致 温度3,4)によって影響を受けるが，ベニザケ Oncorhynchus nerka は, 産卵回遊の間に地域特異的な温度適応を 示すことが示唆されており, 5,6) ニジマスでもよく似た適 応が $29^{\circ} \mathrm{C}$ に達する砂漠の環境で確認されている。7) 高温 選抜系は, 本研究に扔いて比較した 2 系統以外の系統 と比較しても高温耐性に優れていることが予想され, 馴 致温度が高いほど他の系統より高いCTM を示すことが 推察される。

次に, 高温耐性が低い系統と判断した日光系 (N) と 高温選抜系（T）を交配した F1T 系及び F1N 系（母系 をT又はNで示している）のCTMを測定した。メス 親を高温選抜系とした F1T 打よび及びオス親を高温選 抜系とした F $1 \mathrm{~N}$ の CTM は共に $30.1^{\circ} \mathrm{C}$ であり, 高温選 抜系々日光系の雌雄を入れ替えた交雑群間で差は認めら れなかった。また，F2のCTM はメス親を高温選抜系 とした F1T の同胞交配 F2T $\left(30.1^{\circ} \mathrm{C}\right)$ とオス親を高温 選抜系とした $\mathrm{F} 1 \mathrm{~N}$ の同胞交配 $\mathrm{F} 2 \mathrm{~N}\left(30.2^{\circ} \mathrm{C}\right)$ に差は認 められなかった。すなわち, 高温選抜系より明らかに CTM が低い標準系と高温選抜系を交配した F1は, 雌 雄の何れが高温選抜系であっても CTM が標準系より高 く, 高温選抜系 F0 とは差がなく, その完全同胞のF2 でも CTM が標準系より高かったことから, 高温選抜系 と他系統との交配により高温耐性に優れた個体群を作出 できることが示唆された。

さらに, F19変動係数は 0.50 と 0.53 であったが, F2 では 0.88 と 1.36 と変異が大きかったことから, 表 現型の変異の広がりが確認され, F2 以降の選抜が効率 的な育種に繋がると考えられた。

\section{4. 改良した選抜指標の検証}

CTM 実験の場合, 馴致温度から CTM をでの水温上 昇が体温上昇と大幅な時間差がなく, 8 体温が環境温度 に追従できる一定割合で数時間かけて上昇する。 方, 魚が CTM で平衡を失う時間として定義されている 有効時間（ET）を高温耐性の評価指標としている研究 もある。 ${ }^{9,10)} \mathrm{CTM}$ と ET は高温耐性の表現型を正しく評 価するものの, 時間がかかり, 1 つの実験で少数の個体 
しか検査できない。さらに，CTM に達した個体は，実 験後に死亡する可能性が高い。そこで, 馴致温度から直 接 CTM 付近の水温に暴露して $\mathrm{ET}$ を測定する方法に よって試行錯誤したところ, $17^{\circ} \mathrm{C}$ 馴致では $28^{\circ} \mathrm{C}$ 暴露が 効率的であったため, この手法による ET の選抜育種の 指標としての有效性を検証した。

小型魚は, 大型魚よりも表面積対体積比が高いため水 温の影響を受けやすく, 大型魚よりも体温が急激に上昇 し, 早く平衡言失する。 ${ }^{11)}$ しかし, 高温選抜系でふ化日 が若干異なり体重に有意な差がある大きな早期稚魚（平 均 $1.83 \mathrm{~g}$ ） と小さな晚期稚魚（平均 $0.67 \mathrm{~g}$ ）の ET は, それぞれ平均 41.2 分と 67.1 分を示し, 大きな早期稚魚 が有意に早く平衡喪失した。さらに, F2N 稚魚の ET と体重, 体長の両方の間に高い負の相関関係が観察され たため，ETによって高温耐性を比較するためには類似 の体サイズのグループ間で比較する必要があると考えら れた。過去の研究ではニジマスを含む複数魚種の稚魚か ら若魚・成魚における CTM と体長との間には相関がな かった。 ${ }^{11)}$ 一方, 二ジマスの $\mathrm{ET}$ は, 体サイズと負の相 関, 12) アパッチトラウト Oncorhynchus gilae apache とリ オグランデカットスロート Oncorhynchus clarkii virginalis では, CTM と体サイズに負の相関, 11) ブルーギ ル Lepomis macrochirus は大型魚の平衡喪失温度が小型 魚より低いことが報告されている。本研究の結果を含 めても魚体の熱交換率だけでは, ET と魚体サイズの関 係を説明することは難しい。本研究で見られた小型魚が 示した長い ET は, 小型魚の代謝が大型魚より小さいこ とに関係していると推察される。平均体重に有意差のな い日光系と F2T 及び F2N の稚魚を比較した時, ET は F2T 稚魚（52.8 分）打よび F2N 稚魚 (60.9 分) が日 光系（40.5 分）より有意に長かった。これらの結果は, 熱交換率が同一であっても系統間で ET に差があること を意味し, 高温選抜系から生産された F2 稚魚が, 高温 耐性の表現型を獲得したことを示唆しており，CTMを 測定した前述の研究の結果と一致していた。13)

成長の良い系統を育種する際に選抜の指標として体重 や肥満度等が用いられるが, 養殖二ジマスの体重と肥満 度の変動係数は，それぞれ 21 と $17 \%$ であるが, 14 ) 対照 的に我々の以前の研究で F2 稚魚の CTM の変動係数は 0.88 と $1.36 \%$ であって, ${ }^{13)}$ 本研究において計測された ETの 16〜 39\%の変動係数は, ET が高温耐性の選抜 指標として CTM より有用であることを示唆している。

致死的な高温ストレスの反応には 3 つの段階があ り, 第 1 段階は異常な行動を特徵とし, 第 2 段階は平 衡喪失を伴い, 第 3 段階では鰓蓋運動が停止し死亡す る。15) ブラウントラウト Salmo trutta を高温ストレス応 答の第 1 抢よび第 2 段階から低温の水に移した場合, 通常, 回復できることがわかっている。15) 本研究に抢い
て, 同様に第 2 段階の平衡喪失状態からほぼ全個体が 回復したことは, 生きた個体を必要とする選抜育種を行 う際に, 高温耐性形質の指標として, ET が有用できる ことを示唆している。

今後は, ET の再現性や実際の育種への応用について 研究する必要がある。

\section{謝辞}

本賞に推薦頂いた東京大学 渡部終五名誉教授, 浅川 修一教授にお礼申し上げます。

本研究は, 東京大学 渡部終五名誉教授の御指導, 御 鞭撻の下に行われたもので, 深く感謝申し上げます。ま た，ニジマスの CTM, $\mathrm{LT}_{50}$ の測定に関する実験方法 について詳細な御助言および御協力をいただいた財団法 人海洋生物環境研究所 土田修二博士, 自発㨟䭒に関す る実験の計画の立案に打いて数多くの御助言と御協力を いただいた東京海洋大学 延東真名誉教授, 本研究に とって重要なニジマスの高温選抜系の育種に関する過去 の資料の提供や貴重な御助言をいただいた元宮崎県水産 試験場長 神田美喜夫氏, 高温選抜系ニジマスの各種実 験に際し多大な御協力をいただいた元宮崎県水産試験場 小林分場長 小金丸隆氏, 栗田壽男氏, 兼田正之氏, 毛 良明夫氏並びに職員の皆様に感謝申し上げます。

本研究の一部は, 平成 $21 \sim 25$ 年度地球温暖化対策推 進費委託事業（水産庁増殖推進部研究指導課）によって 実施され, 共同研究において御尽力いただいた国立研究 開発法人水産研究・教育機構中央水産研究所尾島信彦 博士，馬久地みゆき博士，北村章二博士，矢田崇博士， 武藤光司氏, 東京大学 浅川修一教授, 木下滋晴准教 授，アクトメッド(侏) 陳盈光博士に感謝申し上げます。

\section{文献}

1) Ineno $T$, Tsuchida $S$, Kanda $M$, Watabe $S$. Thermal tolerance of a rainbow trout Oncorhynchus mykiss strain selected by high-temperature breeding. Fish. Sci. 2005; 71: 767-775.

2) Currie RJ, Bennett WA, Beitinger TL. Critical thermal minima and maxima of three freshwater game-fish species. Environ. Biol. Fish. 1998; 51: 187-200.

3) Elliott JM. Tolerance and resistance to thermal stress in juvenile Atlantic salmon, Salmo salar. Freshw. Biol. 1991; 25: $61-70$.

4) Berger EM, Woodward MP. Small heat-shock proteins in Drosophila may confer thermal tolerance. Exp. Cell Res. 1983; 147: 437-442.

5) Lee CG, Farrell AP, Lotto A, MacNutt MJ, Hinch SG, Healey MC. The effect of temperature on swimming performance and oxygen consumption in adult sockeye $(\mathrm{On}$ corhynchus nerka) and coho (O. kisutch) salmon stocks. $J$. Exp. Biol. 2003; 206: 3239-3251.

6) Eliason EJ, Clark TD, Hague MJ, Hanson LM, Gallagher ZS, Jeffries KM, Gale MK, Patterson DA, Hinch SG, Farrell AP. Differences in thermal tolerance among sock- 
eye salmon populations. Science 2011; 332: 109-12. doi: 10.1126/sience.1199158.

7) Pickering $\mathrm{AD}$. Rainbow trout husbandry: management of the stress response. Aquaculture 1992; 100: 125-139.

8) Cox DK. Effects of three heating rates on the critical thermal maximum of bluegill. In: Gibbons JW, Sharitz RR (eds). Thermal Ecology. CONF-730505, Nat. Tech. Inf. Serv., Springfield. 1974; 158-163.

9) Perry GML, Danzmann RG, Ferguson MM, Gibson JP. Quantitative trait loci for upper thermal tolerance in outbred strains of rainbow trout (Oncorhynchus mykiss). Heredity 2001; 86: 333-341.

10) Danzmann RG, Jackson TR, Ferguson MM. Epistasis in allelic expression at upper temperature tolerance QTL in rainbow trout. Aquaculture 1999; 173: 45-58.

11) Recsetar MS, Zeigler MP, Ward DL, Bonar SA, Caldwell CA. Relationship between fish size and upper thermal tolerance. Trans. Am. Fish. Soc. 2012; 141: 1433-1438.

12) Perry GML, Matyniuk CM, Ferguson MM, Danzmann RG. Genetic parameters for upper thermal tolerance and growth-related traits in rainbow trout (Oncorhynchus mykiss). Aquaculture 2005; 250: 120-128.

13) Ineno $T$, Tamaki K, Yamada K, Kodama R, Tsuchida $S$, Tan E, Kinoshita S, Muto K, Yada T, Kitamura S, Asakawa S, Watabe S. Thermal tolerance of a thermally selected strain of rainbow trout Oncorhynchus mykiss and the pedigrees of its $\mathrm{F} 1$ and $\mathrm{F} 2$ generations indicated by their critical thermal maxima. Fish. Sci. 2018; 84: 671679.

14) Gjedrem T. Genetic improvement of cold-water fish species. Aquac. Res. 2000; 31: 25-33.

15) Elliott JM. Some aspects of thermal stress on freshwater teleosts. In: Pickering AD (eds). Stress and fish. Academic Press, London. 1981; 209-245. 